\title{
Leadership Quality for Malaysia Construction Leader to Steer a Success Construction Project
}

\author{
Nur Ain Ngah Nasaruddin ${ }^{1, a}$ and Ismail Abdul Rahman ${ }^{1}$ \\ ${ }^{1}$ Faculty of Civil and Environmental Engineering, Universiti Tun Hussein Onn Malaysia, 86400 Parit Raja, Johor, \\ Malaysia
}

\begin{abstract}
Issues that dominate the construction industry for the long time such as time overrun, cost overrun, quality of construction and also safety during the construction process are difficult to resolve because of several factors involved which amongst them are leadership quality in the industry. Solving these issues can make the industry more sustainable in nature. This paper presents the need of leadership quality among construction parties involved to steer a construction project successfully. Literature work found that 11 leadership qualities to ensure construction project success. From the frequency analysis, five most dominant leadership qualities are team building, communication skill, visioning, planning \& strategy skill, and decision making. Beside the literature, this study also seeks an opinion from a senior leader of a successful construction company regarding the need of these qualities amongst parties to resolve the construction issues. The results from an interview session indicate that he fully agreed with the need of all the qualities in the construction industry. This shows that there is a strong relationship between solving the issues with the leadership quality in ensuring construction project success. These qualities should be further investigated to acquire a better representation of leadership quality in resolving construction issues for Malaysia construction industry.
\end{abstract}

\section{Introduction}

In nature, construction industry is a labor intensive, needs skills \& commitment, and effective organization of manpower [1]. It is considered as one of the world's largest industries that holding $18 \%$ of gross domestic product (GDP) [2]. In the construction project implementation process, it involves activities such as planning, designing, and executing of the projects from beginning to completion for controlling time, scope, cost and quality [3]. Thus, the implementation of the project requires construction leaders who can play an important role in ensuring that the processes are undertaken smoothly.

Construction leaders from management team may vary either they are from contractors, site engineers, project managers and project site supervisors. Basically, the qualities of leadership during project execution affect project performance either positively or negatively [2]. According to [4], leadership is the ability to guide the project team in achieving project objectives and balancing project constraints. Therefore, good construction leaders need to be an effective and successful strategist [5].

\footnotetext{
${ }^{\text {a }}$ Corresponding author : nurain_ngah@yahoo.com
} 
An effective leader is built from inference, experience and instinct [6]. Whereas, strategic leaders generate a viable organization that will be capable of working in all circumstances [7].

\section{Construction Project Failure}

A construction project is considered fail if it faced cost and time overruns, not meeting the required quality as stipulated in the contract document and faced with safety issue during the construction.

\subsection{Issues on time overrun}

Time overrun can be defined as the non-completion of the project within the original or agreed contract period [8]. It can be caused by several factors including the lack of building materials, changes to the original designs, and new requirements being added to the original plan, etc [9]. However, in real life situations, many projects have been delayed due to changing of main contractor after work had started [9]. Statistics show that only $20.5 \%$ and $33.35 \%$ of public sector and private sector projects respectively are completed within the time specified in the contracts in Malaysia [10]. Therefore, there is a need to have good construction leaders who are able to control the construction process by avoiding or minimizing time overrun.

\subsection{Issues on cost overrun}

According to [11] defined construction cost as the degree to which the general conditions promote the completion of a project within the estimated budget. However for cost overrun occur when the final cost of the project exceeds the original estimates [12]. Significantly, construction projects facing cost overrun due to fluctuation in price of raw materials, lack of experience, unforeseen site conditions, high cost of machineries, and inaccurate or poor estimation of original cost [13]. In Malaysia only $46.8 \%$ and $37.2 \%$ of public sector and private sector projects respectively are completed within the budget [10]. Construction leader who able to manage effectively and strategically the project will keep the cost within the budget.

\subsection{Issues on quality}

Quality is defined as meeting the customer's expectations, or compliance with customer's specification according to appearance, performances, and reliability of the project for a given price range [14]. However, quality may sometimes be ignored in construction industry in order to reduce the costs or to shorten the project time [15]. A surveys conducted by [16] identified several unethical conducts and ethical dilemmas in the construction industry such as corruption, negligence, conflict of interest, bid cutting, under bidding, collusive tendering, cover pricing, frontloading, bid shopping, withdrawal of tender, and payment game. Significantly, a study by [17] show that majority of $72.7 \%$ construction leader agreed that unethical conduct can be the main cause for poor quality project.

\subsection{Issues on safety}

Safety has been a major issue and concern in the construction industry when it comes to work-related accidents [18]. According to [19], in 2014, Malaysia construction accident show that 72 workers die at the job site as a result of work, 6 workers suffering permanent disability, and 94 workers suffering non-permanent disability. From previous studies by [20], among the factors that lead to the construction accidents are the workers' negligence, failure of workers to obey work procedures, work at high elevation, operating equipment without safety devices, poor site management, harsh work operation, lack of knowledge, low skill level of workers, failure to use personal protective equipment's, and poor workers attitude about safety. 


\section{Importance of Construction's Leadership Quality}

Like the other effort, the importance of leadership quality to construction project success are to ensure the smooth running of projects [21], to satisfy conflicting requirements in support of organizational success [2], to increase the company's profitability [22], to create new opportunities for companies to apply its skills [22], and to develop leader to professional ladders [2].

With good quality of construction's leader a project will run smoothly with less disruption due to project constraints; such as tight schedule and budget, limited resource, risky and others [4]. Good construction leader should be able to recognize project strength, weakness, opportunity, and threat in order to complete construction project successfully. These will increase company profit because less or no repetition of works and also delay. Furthermore, proactive leaders tend to create new opportunities rather merely completing the projects. Also, good leaders with ethical behavior will lift their images in their profession.

\section{Research Methodology}

This study was involved in several lists of step as below:

i. Identified Relevant Reference. Identification of relevant references should be geared to the quality of leadership of the construction practitioners. The reference is covering from books and journal articles.

ii. Able to Identify and Extract Important Fact or Point Related to Study. A thorough literature work of research articles was conducted to identify the leadership quality in the construction industry.

iii. Organized the Facts into Systematic Manner. For instance, listing the leadership quality and estimating frequency for all the quality. Descriptive statistic using frequency was used in order to analyze and interpret the result into a meaningful form.

iv. Similarity Checking. The process involves checking the fact obtained. The purposes of these approaches are to avoid duplication of points or facts, generalization of several points or facts, and rephrase or reword the facts according to the study.

v. Verification from the Expert. An interview session with senior successful construction leaders in Malaysia was carried out to strengthen the information obtain from the literature review. Besides, an interview session was carried out to give an insight view of Malaysia construction regarding the leadership quality required to steer a successful construction project.

\section{Leadership Quality to Tackle Issues}

One of the main components in ensuring a success of a construction project is the leadership quality amongst construction leader. A good leader will be able to manage the project effectively and also be able to strategize construction activities based on the risk management approach. With proper leadership skill among the construction parties will enable to navigate the construction process in a sustainable manner. It is time for Malaysia to have a sound leader quality among the construction parties to make sure our construction industry attain world standard by 2020 as envision being developed country. Features of leadership quality are extracted from research articles produced by researchers who explored the leadership quality amongst the construction parties as in Table 1.

Table 1 indicates that there are 11 quality features that are being noted by researchers in the field of construction. Out of these 11 features the 5 most highlighted by the researchers are team building, communication skill, visioning, planning \& strategy skill and decision making. From the literature analysis, an interview session with construction leader was carried out to give an insight view of Malaysia construction regarding the leadership quality required to steer a successful construction project. 
Table 1: Leadership quality for construction project success

\begin{tabular}{|c|c|c|c|c|c|c|c|c|c|}
\hline \multirow{2}{*}{ No. } & \multirow{2}{*}{ Leadership Quality } & \multicolumn{7}{|c|}{ Construction Industry Related Sources } & \multirow{2}{*}{ 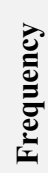 } \\
\hline & & $\mathbf{A}$ & B & $\mathbf{C}$ & $\mathbf{D}$ & $\mathbf{E}$ & $\mathbf{F}$ & $\mathbf{G}$ & \\
\hline 1 & Communication skill & $\sqrt{ }$ & $\sqrt{ }$ & $\sqrt{ }$ & & $\sqrt{ }$ & & & 4 \\
\hline 2 & Team building & $\sqrt{ }$ & $\sqrt{ }$ & & $\sqrt{ }$ & $\sqrt{ }$ & & $\sqrt{ }$ & 5 \\
\hline 3 & Decision making & $\sqrt{ }$ & & & & $\sqrt{ }$ & & $\sqrt{1}$ & 3 \\
\hline 4 & Sense of responsibility & & & $\sqrt{ }$ & & & $\sqrt{ }$ & & 2 \\
\hline 5 & Visioning & & $\sqrt{ }$ & & $\sqrt{ }$ & & $\sqrt{ }$ & $\sqrt{ }$ & 4 \\
\hline 6 & Planning \& strategy skill & & $\sqrt{ }$ & $\sqrt{ }$ & $\sqrt{ }$ & & & $\sqrt{ }$ & 4 \\
\hline 7 & Relationship management skill & & & & & $\sqrt{ }$ & & $\sqrt{ }$ & 2 \\
\hline 8 & Empowerment & $\sqrt{ }$ & $\sqrt{ }$ & & & & & & 2 \\
\hline 9 & Ethics & $\sqrt{ }$ & & & & & & & 1 \\
\hline 10 & Influencing & & $\sqrt{ }$ & $\sqrt{ }$ & & & & & 2 \\
\hline 11 & Integrity & & & & & $\sqrt{ }$ & $\sqrt{ }$ & & 2 \\
\hline
\end{tabular}

(Sources: A [23], B [24], C [25], D [26], E [27], F [28], G [29])

\section{Interview with Construction Leader}

An interview was carried out with one of the prominent and successful construction leader in the northern part of peninsular Malaysia regarding his opinion on the importance of leadership quality to steer success of his construction company. He is managing director from grade G7 contractor company with more than 30 years of experiences in construction industry. In the interview session, he mentioned that to be a good leader in construction industry, one must possess qualities such as honesty and trust with the employees, teamwork, planning, time management, decision making, empowerment, and good communication.

He emphasized that as leaders in implementing construction project, they have to be knowledgeable and skillful in handling their worker or might lose them. For example, issue like a wage dispute between workers is quite famous where the workers tend to demand more. With strong relationship quality, leaders will be able to treat all employees fairly and equitably, and caring for the welfare of workers. As leaders they should be able to manage risk such as price of construction material increase due to economic fluctuation and also late payment from the client. With good quality leaders, they will able to anticipate possible kinds of risk in the implementation of the project. Improper handling of these issues, my result to cost and time overrun which lead to project failure, thus it there is a strong correlation between the leadership with the project failure.

\section{Conclusion}

This study has provided an insight issues in construction project implementation which needs a strong leadership quality. It can be stated that there is no single leadership quality is suitable in all project circumstances. As construction leaders, they must use their knowledge and skills to adopt or adapt any specific leadership quality based on work that need to be done. If the issues are tackled with strong leadership quality, the leaders can become as role models to their employee.

\section{References}

[1] R. Morton and A. Ross, Construction UK: Introduction to the Industry, Oxford, (2008).

[2] R. Udhayakumar and P. Karthikeyan, Expected leadership qualities for a project manager to manage construction projects, Int. J. of Innovative Research and Development, 3, 57-61, (2014). 
[3] J.J. McKeon, Becoming a Construction Manager, New Jersey, (2011).

[4] PMBOK Guide, A Guide to the Project Management Body of Knowledge, Project Management Institute, United States, (2008).

[5] http://www.stuba.sk/new/docs/stu/ustavy/ustav_manazmentu/NAB2012-2/ clanok9.pdf.

[6] K. Gharehbaghi and K. McManus, The construction manager as a leader, Leadership and Management in Engineering, 3(1), 56-58, (2003).

[7] http://www.alnmag.com/articles/2011/06/three-levels-leadership.

[8] D.A.R. Dolage and D.L.G. Rathnamali, Causes of time overrun in construction phase of building projects: A Case Study on Department of Engineering Services of Sabaragamuwa Provincial Council, The Institution of Engineers, Sri Lanka, 66(3), 9-18, (2013).

[9] http://www.thestar.com.my/Opinion/Letters/2015/04/28/Minimising-project-delays/.

[10]I.R. Endut, A. Akintoye and J. Kelly, Cost and time overruns of projects in Malaysia, Proc. of the 2nd Scottish Conference for Postgraduate Researcher of the Built and Natural Environment, 243252, (2005).

[11]E.W.M. Lam, A.P.C. Chan and D.W.M. Chan, Benchmarking success of building maintenance projects, Emerald Insight, 28(5/6), 290-305, (2010).

[12]N. Azhar, R.U. Farooqui and S.M. Ahmed, Cost overrun factors in construction industry of Pakistan, Proc. of the First International Conference on Construction in Developing Countries, 499-508, (2008).

[13]A.S. Ali and S.N. Kamaruzzaman, Cost performance for building construction projects in Klang Valley, Journal of Building Performance, 1(1), 110-118, (2010).

[14]K.N. Jha and K.C. Iyer, Critical factors affecting quality performance in construction projects, Total Quality Management, 1155-1170, (2006).

[15]A.M. Turk, ISO 9000 in construction: An examination of its application in Turkey, Building and Environment, 501-511, (2006).

[16]C. Vee and M. Skitmore, Professional ethics in the construction industry, Engineering, Construction and Architectural Management, 10(2), 117-127, (2003).

[17]H. Abdul-Rahman, C. Wang and X.W. Yap, How professional ethics impact construction quality: Perception and evidence in a fast developing economy, Scientific Research and Essays, 5(23), 3742-3749, (2010).

[18]M. Alhajeri, Health and Safety in the Construction Industry: Challenges and Solutions in the UAE, PhD Thesis, Coventry University, (2014).

[19] http://www.dosh.gov.my/index.php?option=com_content\&view=article\&id=1225:occupationalaccidents-statistics-by-sector-2\&catid=502\&Itemid=1280\&lang=en.

[20]A.R.A. Hamid, M.Z.A. Majid and B. Singh, Causes of accidents at construction sites, Malaysian Journal of Civil Engineering, 20(2), 242 - 259, (2008).

[21]M. R. Senam, K. Abdul Rashid, A. A. Sarkawi and R. M. Zaini, construction project leadership from the perspective of Islam, International Journal of Islamic Thought, 6, 46-56, (2014).

[22]D.B. Russell, D.D. Dunne, How Healthy is your company's leadership development culture?, Construction Management Association of America, 1-13, (2004).

[23]J.V. Farr, S.G. Walesh and G.B. Forsythe, Leadership development for engineering managers, Journal of Management in Engineering, 13(4), 38-41, (1997).

[24] V.K. Verma and R.M. Wideman, Project manager to project leader? and the rocky road between, Project Management Institute's 25th Annual Seminar and Symposium, 1-9, (1994).

[25]B. Benator and A. Thumann, Project Management and Leadership Skills for Engineering and Construction Projects, Unites States, (2003).

[26]http://www.maconline.org/tech/ estimating/newsletter.pdf.

[27]A.R.J. Dainty, M. Cheng and D.R. Moore, Competency-based model for predicting construction project managers' performance, Journal of Management in Engineering, 21(1), 2-9, (2005).

[28] http://www.rhgraham.org/RHG/Recent_publications_files/ELE\%20White\%20 Paper-102109.pdf

[29]P.P. Bhangale and R. Devalkar, Study the importance of leadership in construction projects, International Journal of Latest Trends in Engineering and Technology, 2(3), 312-318, (2013). 